 \\ $\underline{\text { Religijski zaokreti }}$
}

Izvorni članak UDK 82:1(045)

doi: $10.21464 /$ fi36207

Primljeno 20. 12. 2015.

\section{Ivan Šarčević}

Franjevačka teologija, Aleja Bosne Srebrene 111, BA-71101 Sarajevo

ivansarst@gmail.com

\section{Intelektualac između fanatizma i cinizma}

\begin{abstract}
Sažetak
U ovom članku nastoji se odgovoriti na pitanje tko su intelektualci i koliko su potrebni društvu i Crkvi? Naime, bezbroj intelektualaca, među njima i teolozi, sudjelovalo je i sudjeluje u stvaranju i podržavanju destruktivnih suvremenih ideologija, religijskih fanatičnih pokreta $i$ ciničnih politika. U bivšim socijalističkim zemljama angažirani humanisti, glavni nositelji slobode, disidenti i stradalnici, često su bili upravo intelektualci. U postsocijalističkim društvima i državama, pogotovo u našima na jugoistoku Europe, pogođenim ratovima $i$ nacionalizmima te zahvaćenim tržišnom i konzumerističkom površnošću, intelektualci/teolozi su uz političare među najvećim kočničarima humanizacije društva: isključuju moral iz politike, odbacuju samokritičnost, građansku hrabrost te proročku dimenziju vjere.
\end{abstract}

\section{Ključne riječi}

intelektualac, teolog, fanatizam, cinizam, odgovornost, ime Božje, angažiranost, (samo)kritičnost, prosvjetiteljstvo

\section{Uvod}

Traženi i odbacivani, hvaljeni i omraženi, intelektualci su od antike, pa preko urbanizacije i razvoja sveučilišta u srednjem vijeku, ${ }^{1}$ a posebno od prosvjetiteljstva, u središtu društvenih događanja - nekada su protagonisti, a nekada glavna zapreka poboljšanju stanja. Usprkos činjenici da su mnogi intelektualci kreatori kobnih ideologija i opasnih mitova, podupiratelji i sluge zločinačkih vođa i režima, usprkos tome što su, kako ističe Mirko Kovač, »elita gora od rulje «, ${ }^{2}$

Usp. Jacque Le Goff, Intelektualci $u$ srednjem vijeku, Naklada Jesenski i Turk, Zagreb 2009.

\section{2}

$»$ Elita gora od rulje $\ll$ naslov je knjige pisca Mirka Kovača koji se, kao rijetko tko kod nas, bavio raskrinkavanjem izopačenih intelektualaca, ideologa zločina i ratnih zločinaca. »Pisci, novinari, filozofi, povjesničari« - piše Kovač - »koji su u jedva minulim balkanskim orgijanjima činili zlodjela, bilo kao ideolozi ili izravno kao zapovjednici, ugnijezdili su se u našu memoriju. [...] Oni nas čine suučesnicima u mržnji, bude naše nagone za osvetom, potiču naša loša svojstva, jer vele da i pravdoljublje može prikrivati neku okrutnost.« Mirko Kovač, Elita gora od rulje. Polemika, Fraktura, Zaprešić 2009., str. 151.

$\mathrm{Na}$ srpsku političku i intelektualnu »elitu« 20. i 21. stoljeća odnosi se vrijedna knjiga: 
koja iza sebe ostavlja nesreće i rijeke krvi, intelektualce se ipak razumijeva ili se od njih traži da budu uzori humanosti.

Intelektualac je tvorac ideja i vizija, duhovno otvoren, budan, neprilagodljiv kolektivizmu, autonoman u mišljenju i djelovanju, često autsajder unutar vlastite zajednice, disident režima, društveno prezren i izoliran; subverzivni pojedinac do mjere da ga se proglasi štetnim i opasnim, izdajnikom naroda i države, razaračem dogmi ili krivovjernikom. Intelektualca ne označava moć kao dominacija nad drugima ni bogatstvo kao cilj njegova djelovanja, nego razboritost, zahtjev istine i pravde, čistoća savjesti, kritičnost i samokritičnost, hrabra odgovornost za druge, za cjelinu i svijet.

\section{Različita značenja i uloge intelektualca}

Nije lagano, bez ostatka, definirati tko bi zapravo bio intelektualac, ${ }^{3}$ posebno s obzirom na društveni angažman ili, još specifičnije, u odnosu na politiku i vlast kako se intelektualce zadnjih stoljeća većinom promatra. Gotovo je to nemoguće, što zbog iznimnog mnoštva literature o njima, što zbog različitosti mišljenja. U antici je intelektualac smatran filozofom, ljubiteljem, posrednikom i učiteljem mudrosti, tražiteljem istine bitka i počela svih stvari; kreposnim čovjekom koji razborito vlada sobom, svojim osjetilima, riječima i ponašanjem.

U srednjem vijeku, uz antičko nasljeđe, intelektualca se smatra ljubiteljem knjige (uz knjige starih filozofa i znalcem Sv. pisma i patristike), prevodiocem s klasičnih jezika, misliocem, pedagogom i učiteljem znanja. Uz to, srednjovjekovni intelektualac bio je pobožan čovjek koji se »profesionalno« zanimao za transcendentnu zbilju, za stvari vjere i razuma, čovjeka i Boga. Promatrao je i prosuđivao ovostranost, ovozemaljski život i državu (razvoj crkvenoga/kanonskoga prava iz rimskoga prava) kroz kategoriju vječnosti i vječnih istina (sub specie aeternitatis), kroz »Božju državu« i Božji konačni sud. ${ }^{4}$

\section{1. "Elita" protiv režima ili uz režim}

U novom vijeku, s Francuskom revolucijom, a osobito od kraja 19. stoljeća, kada i nastaje suvremeni pojam intelektualca, naglasak se premješta na promatranje intelektualca u njegovoj društvenoj relevantnosti i prema njegovu utjecaju na javnost. Za vrijeme Dreyfusove afere ${ }^{5}$ profilira se današnji tip intelektualca, najprije kao poruga, ${ }^{6}$ a zatim se - na figuri utemeljenoj na filozofima i enciklopedistima 18. stoljeća - intelektualca smatra autonomnim pojedincem koji, vjeran svojoj savjesti i istini, u javnosti kritički hrabro raskrinkava laž, korupciju i zlo vlasti i režima.

Za razliku od prijašnjih vremena (npr. vremena procesa i osuda intelektualaca poput Savanarole, Husa, Morea, Bruna, Erazma, Galileja...), intelektualac nije više toliko sam, nego intelektualci nastupaju zajedno u javnosti, formiraju se kao određena društvena »elita« koja mijenja javno mišljenje te utječe na društvene promjene. Intelektualci se u obrani nedužno optuženoga židovskog časnika Alfreda Dreyfusa, sažima Ivan Bubalo, proglašavaju

»... demokratima po političkoj orijentaciji te onima koji se pozivaju na savjest kao vrhovnu moralnu instanciju i na znanost kao jedini put dolaska do istine, koji su politizirani u tom smislu što smatraju da pojedinac ne smije izbjegavati odgovornost i zauzetost za opće stanje u društvu, te oni koji su mladenački okrenuti budućnosti «. ${ }^{7}$ 
Drukčije poimanje intelektualaca događa se u Rusiji krajem 19. stoljeća. Ondje se za intelektualce koristi zbirna imenica »inteligencija«, termin psihološkofilozofskoga podrijetla. U boljševičkoj Rusiji za intelektualca je presudno da raskida s »buržoazijom« (i religijom), veže se uz revolucionarni pokret i radničku klasu. Komunistička vlast govori o tzv. »poštenoj inteligenciji«, »borbenoj inteligenciji $\ll,{ }^{8}$ avangardi besklasnoga društva. Intelektualac je ideolog i ideološki jamac revolucionarnog pokreta i sistema. Dolazi do »svođenja logosa na praxis $\ll,{ }^{9}$ do izjednačavanja inteligencije i radničke klase, intelektualca

Latinka Perović, Dominantna i neželjena elita. Beleške o intelektualnoj i političkoj eliti u Srbiji ( $X X-X X I$ vek), Graf, Javna medijska ustanova »Radio-televizija Vojvodina«, Beograd, Novi Sad 2015.

O poteškoćama s terminom »intelektualac«, njegovim značenjima i ulozi intelektualca usp. Živan Bezić, »Tko je i što je intelektualac?«, Crkva u svijetu 4 (1988), str. 331-341.

Usp. Jacque Le Goff, Intelektualci u srednjem vijeku, str. 57. Le Goff navodi i struju koja se opirala urbanizaciji, novonastalim sveučilištima, osobito onom pariškom, i traži napuštanje gradova i povratak prirodi, među njima posebno sv. Bernard (str. 86). I Franjo Asiški, osim prema novcu, sa sumnjom se odnosio prema knjigama jer su skupe i protive se evanđeoskom siromaštvu, kao i prema studiju i školskom stjecanju znanja jer je znanje, smatrao je Franjo, izraz moći. Usp. Raoul Manselli, Franjo Asiški, Svjetlo riječi, Sarajevo 2011., str. 409; Klaus Reblin, Franziskus von Assisi. Der rebellische Bruder, Vandenhoeck \& Ruprecht, Göttingen 2006., str. 78; Jacques Le Goff, Sveti Franjo Asiški, Demetra, Zagreb 2010., str. 195-198.

»Manifest intelektualaca«, objavljen u listu L'Aurore [Zora] 14. siječnja 1898., označava datum službenog rađanja suvremenog intelektualca, a književnik Émile Zola, s otvorenim pismom predsjedniku Francuske J'accuse [Optužujem], postaje primjer takvog intelektualca.

6

$»$ Dreyfusovi protivnici njegove zagovornike nazivaju pogrdno intelektualcima i pritom im prigovaraju da je njihovo mišljenje apstraktno daleko od realnosti a usmjereno protiv instinkta, da nemaju nacionalnog osjećaja, da su po porijeklu ili po usmjerenju Židovi a po karakteru dekadentni te da se miješaju u stvari za koje nisu kompetentni.« Ivan Bubalo, »Teološko obrazovanje u vrijeme krize intelektualaca«, Minima varia: mali razgovori s vremenom, Ex libris, Rijeka 2012., str. 66.

7

I. Bubalo, »Teološko obrazovanje u vrijeme krize intelektualaca«, str. 66.
Značenje termina »borbena inteligencija« preuzimamo od pisca i filozofa Vlade Gotovca, jednog od najznačajnijih i najtragičnijih angažiranih hrvatskih intelektualaca u drugoj polovici 20. stoljeća. Prema Gotovcu riječ je o intelektualcima koji su se u vrijeme hrvatskog proljeća 1971., kako on kaže, sa »staljinskim prezirom« prema pojedincu i neistomišljenicima, dakle i prema njemu, stavili na stranu totalitarne vlasti u progonu, sudskim procesima i likvidacijama. Gotovac ih naziva »odredom borbene inteligencije«, "sastavljen od pisaca, režisera, filozofa, sociologa, politologa (...) - koji je po revolucionarnoj tradiciji svojim komentarima i znanstvenim argumentima pratio pothvate policije i sudstva: denuncirao, pripremao dokaze za suđenje, obrazlagao i branio osude, izazivao obračune, demonizirao atmosferu - poduzimao sve što je potrebno da bi uništavanje okrivljenih dobilo sjaj pravde, koja zaštićuje i temeljne i najuzvišenije ljudske vrijednosti i slobodu u kojoj su jedino moguće.« Vlado Gotovac, Moj slučaj, Cankarjeva založba, Ljubljana, Zagreb 1989., str. 156. O antimodernizmu, iracionalizmu i antiintelektualizmu fašizma usp. Umberto Eco, »Vječni fašizam«, dostupno na: http://pescanik.net/vjecni-fasizam/ (pristupljeno 11. 1. 2013.). Eco tvrdi: »Nepovjerenje prema intelektualnom svijetu uvijek je bio simptom ur-fašizma, od navodne Göringove izjave 'Kada čujem riječ kultura, latim se pištolja', do učestalih izraza kakvi su 'degenerirani intelektualci', 'štreberčine i pametnjakovići', ‘jalovi snobovi' ili ‘univerziteti su legla crvenih'. Zvanični fašistički intelektualci uglavnom su bili zaduženi za napade na modernu kulturu i liberalnu inteligenciju koja je navodno izdala tradicionalne vrijednosti.«

9

Usp. Michel Mazzola, »Od intelektualca kod Marxa do marksizma intelektualaca«, Marksizam u svetu 1-2 (1977), str. 150-158. »Podređeni potpunoj politizaciji i nepodnošljivim prohtjevima jednog djelovanja koje tvrdi da je obuhvatilo logos, dok ga u suštini uništava, izvjesni intelektualci vjeruju da su izbjegli misao bez akcije, dok se međutim sami nalaze u akciji bez misli, u kojoj efikasnost smatraju kriterij istine a oportunizam brkaju s dijalektikom« (str. 156). 
i radnika proizvođača. Intelektualac se i naziva »intelektualnim radnikom «. ${ }^{10}$ U konačnici »poštena inteligencija« se poistovjećuje s vladajućom politikom i vlašću Partije. Jedan od najvećih primjera takve vrste intelektualca jest pisac Maksim Gorki za vrijeme Staljina. ${ }^{11}$

\subsection{Ni apolitičnost ni antipolitičnost}

Uza sve prijepore i neslaganje, danas ćemo se složiti da intelektualac treba biti znalac, Sartre bi kazao čovjek univerzalnoga znanja, ${ }^{12}$ bistre inteligencije, oštrouman, inventivan i kritičan, premda formalno ne treba završiti visoke škole ni steći diplomu, te da svoje znanje logički sintetizira, argumentirano javno posreduje. Društveni položaj i zvanje u smislu profesije po sebi ne čine intelektualca intelektualcem, iako postoje »intelektualne profesije«, većinom akademski obrazovani građani humanističkih znanosti, poput učitelja (profesora), pisaca, povjesničara, politologa, pravnika, svećenika, teologa, novinara, glumaca, dok se tzv. tehničke profesije rjeđe ubrajaju u intelektualce.

Teško će se, međutim, naći suglasnost treba li današnji intelektualac biti krepostan ili bogobojazan, kao u prijašnja vremena. Još je teže odgovoriti na pitanje treba li i do koje mjere intelektualac biti društveno ili politički aktivan. Sami se »intelektualci« dijele i spore po tom pitanju. Dok jedni smatraju da je za intelektualca presudno da se društveno angažira, ${ }^{13}$ da se uplete u politiku (i onu dnevnu) kao iznimno »častan « ljudski posao, drugi će smatrati da intelektualac treba stajati distanciran od svake politike jer je suvremena politika nemoralna i parcijalna, "prljavo« ljudsko djelovanje, nedostojno časnih ljudi. ${ }^{14}$ Upravo oko ove dvije mogućnosti i dva izbora, oko društvene uloge intelektualca (mislimo pritom i na teologa), oko njegove etičke odgovornosti za svijet i kritičkoga odnosa prema društvenoj stvarnosti i socijalnim problemima, sučeljavaju se današnja mišljenja i vode rasprave. I ovo će razmišljanje ići u tom smjeru te uza sve najbolje nakane neće biti lišeno privilegiranja određene opcije, kao ni zauzimanja subjektivnoga stava koji nosi karakter relativnosti, ali i pozitivne provokacije. Upuštamo se u dijalog i izlažemo kritici i neslaganju čitatelja. Pritom upućujemo i na šire bilješke kojima također želimo istaknuti kompleksnost naše teme i potaknuti čitatelja na vlastito mišljenje i istraživanje.

Ako, naime, čovjeka razumijevamo kao društveno biće, a politiku kao brigu za društvo i zajedničko dobro, pri čemu je poštivanje i obrana dostojanstva svakoga pojedinca polazište, kriterij i granica tog političkog djelovanja, onda se nitko, a pogotovo ne intelektualac, ne može lišiti političke odgovornosti, niti skloniti izvan svijeta u kakvu anahoretsku antipolitičnost ni apolitičnost. Sudjelovanje u političkom životu neotklonjiva je moralna obveza. ${ }^{15} \gg \mathrm{U}$ modernoj državi«, tvrdi filozof Karl Jaspers, »politički djeluje svatko, u najmanju ruku glasanjem na izborima ili neizlaženjem na izbore. Smisao političke odgovornosti nikome ne dopušta uzmak «. ${ }^{16}$ C̆ak i »u pristajanju na nemoć« - zaključuje Jaspers - »uvijek postoji prostor, doduše bezopasne, ali uz oprez ipak djelotvorne aktivnosti ${ }^{17}{ }^{17}$ Svijest o odgovornosti (i krivnji), svijest je slobode, političke slobode koja je uvjet da se uopće bude slobodan, da se bude čovjekom, a time onda i intelektualcem.

\section{Odgovorna društvena angažiranost}

Što razlikuje intelektualce od drugih ljudi? Polazimo od opće činjenice da intelektualac dijeli isto vrijeme i prostor, istu društvenu situaciji sa svojim suvremenicima. No ta situacija za intelektualca nije zadovoljavajuća. Nije, međutim, zadovoljavajuća ni za čovjeka koji nije intelektualac. I on se, često 
i teže nego redovito osiguraniji i privilegiraniji intelektualac, osjeća uvjetovanim i neslobodnim, obespravljenim u društvu. Razlika je, čini se, u razabiranju, razumijevanju stvarnosti; u onom što i znači latinska riječ 'intellectus', u spoznajnoj moći i kvaliteti znanja, kao i, nipošto na zadnjem mjestu, u obrazlaganju »zajedničke« situacije, u sposobnosti stvaranja pojmova na osnovi stečenoga znanja, kao i na osnovi osobnoga i zajedničkoga iskustva, ali koje se javno posreduje u odgovornosti za cjelinu, naročito u odgovornosti za društveno obespravljene.

Moglo bi se kazati da prvo što čini intelektualca intelektualcem jest šire, dublje i temeljitije znanje, praktična mudrost uređenja složene i nepregledne stvarnosti (sapientis est ordinare), ${ }^{18}$ te vješta i prikladna jezična sposobnost

10

Marksistički filozof Arif Tanović piše da je »jedini put za razrješenje bitnih, ako ne svih problema i dilema oko inteligencije, u udruženom radu, gdje se intelektualni radnici tretiraju kao i svi drugi proizvodni radnici, dakle kao punopravni pripadnici radničke klase i jednakopravni radni ljudi, samoupravljači društvenim sredstvima proizvodnje, koji zajednički odlučuju o uvjetima i rezultatima svoga rada i života«. Arif Tanović, »Intelektualci i radnički pokret«, Marksizam u svetu 1-2 (1977), str. XVI.

11

Usp. Simon Sebag Montefiore, Staljin - na dvoru crvenog cara, Profil International, $\mathrm{Za}$ greb 2009.

12

Jean-Paul Sartre, »Funkcija intelektualca «, Marksizam u svetu 1-2 (1977), str. 1-13. Sartre govori o proturječju kao funkciji intelektualca: prognan od privilegiranih klasa (vladajućih), sumnjiv u očima potlačenih; sam, istodobno odgovoran za sve; nema mandat ni od koga, a mora se uplesti u konkretno i partikularno; biti intelektualac $\mathrm{i}$ istodobno se samokritički osporavati; slobodan, a istodobno najamni radnik proturječnog društva; privilegij znanja kao moći nad drugima, a uvijek u opasnosti da se izjednači s povlaštenim političarom i vlašću.

13

Morin tvrdi da se $\mathrm{u}$ intelektualce ubrajaju ljudi: 1) po kulturno vrednovanoj profesiji sa stanovišta humanističke ili klasične kulture, 2) po društveno-političkoj ulozi i 3) po savjesti koja komunicira $s$ univerzalnim principom uma pa je intelektualac čuvar vrlina, moralna savjest društva. Usp. Edgar Morin, »Intelektualci: kritika mita i mit kritike«, Marksizam u svetu 1-2 (1977), str. 69.

14

Iako se javno pridružio obrani nedužnoga pojedinca pred vlašću, židovskoga časnika Dreyfusa, Julien Benda, kao jedan od najvećih kritičara intelektualaca u politici, smatra da su moderni intelektualci divinizirali politiku, dopustili da politika određuje što je moralno, da su odbacili duhovne, vječne vrednote: razum, istinu i pravdu i priklonili se praktičnom, počeli su služiti redu, partikularnim, nacionalnim interesima, sebičnosti države, praznom aktivizmu i onom najgorem - ratu radi rata. Usp. Julien Benda, Izdaja intelektualaca, Politička kultura, Zagreb 2007., str. 116-153.

15

U svom programskom spisu iz 2013. Radost Evandelja (Evangelii gaudium) Papa Franjo tu obvezu shvaća ovako: »U svakoj naciji stanovnici razvijaju socijalnu dimenziju svoga života djelujući kao zauzeti i odgovorni građani u krilu jednog naroda, ne kao masa koja je potpala pod utjecaj dominantnih moćnika. Sjetimo se da je 'biti vjerni građanin krepost a sudjelovanje u političkom životu moralna obveza'«(EG 220)

16

Karl Jaspers, Pitanje krivnje. O političkoj odgovornosti Njemačke, AGM, Zagreb 2006., str. 50. Ne može, smatra Jaspers, postojati apolitičan stav i nastavlja: »Može se pomisliti: mogli bi postojati ljudi koji su u potpunosti apolitični, čija se egzistencija odvija izvan politike, poput monaha, pustinjaka, znanstvenika, istraživača ili umjetnika. Ako bi oni bili zaista apolitični, ne bi sudjelovali u krivnji. Ali politička odgovornost pogađa i njih jer i oni svoj život ostvaruju kroz poredak države. U modernim državama 'izvan' ne postoji.« (str. 51) »Ne postoji apsolutno lučenje politike od bivanja čovjekom, dok čovjek kao pustinjak ne propadne izvan društva.« (str. 65)

17

K. Jaspers, Pitanje krivnje, str. 58.

18

»Mudrost je tu neka kroz znanje i iskustvo stečena praktična sposobnost da u nepreglednosti životne zbilje ipak pogodi ono pravo, postupi dobro. To mu polazi za rukom također stoga što bistro uviđa svoje granice $i$ one drugih ljudi te one koje se protežu među stvarima, događajima i iskustvima. Zato vrijedi 'sapientis est ordinare' - mudar čovjek unosi red u stvarnost jer poznaje njezine granice.« Stjepan Kušar, Obične stvari i slobodni Bog, Kršćanska sadašnjost, Zagreb 2015., str. 11. 
da riječima, imenima i pojmovima unese red u semantičku zbrku, u jezični babilon i u konflikt interpretacija. Čini to i onda kada nad njegovom zbiljom ne dominiraju samo kriva tumačenja nego i nametnuta (totalitarna) šutnja. Intelektualac je u tom smislu onaj koji značenje pojava i riječi ne prihvaća samorazumljivim, kao što ni rezultate svoje spoznaje i njihovo orječenje ne smatra apsolutnom istinom, nego poznaje svoje granice i granice drugih i smatra se tražiteljem istine.

Intelektualac diferencira, pozoran je na hermeneutički odnos dijelova i cjeline. Uspoređuje svoje uvide s tradicijom mišljenja, s uvidima drugih, stručnijih i većih znalaca i autoriteta od sebe; analizira, sintetizira, pravi razlike pojmova, nanovo imenuje zbilju i događaje. Intelektualac dakle unosi red $u$ stvarnost, ali i »nered «, semantički nemir, karikira zbilju, čini nekonvencionalne geste, poput proroka, do čuđenja i ludosti za okolinu, da bi se pošlo prema istini i pravdi za sve. Nerijetko je zato disonantni, uznemirujući glas u selektivnom ili lažnom govoru ili u lažnom miru jer je ljudski duh strašljiv, umara se, teži ravnodušnosti, životu bez napora mišljenja i bez stvarne promjene djelovanja.

Po svom habitusu intelektualac je onaj koji unosi nova značenja riječi i djela, drukčiji pogled na zbilju. Postavlja u pitanje ili dekonstruira naviknutu ljestvicu vrednota, traži ili uspostavlja novu ili novi raspored vrednota. Njegov cilj je učiniti instituciju, zajednicu i društvo humanijim, pravednijim za sve. Intelektualac je, kako ga razumijeva intelektualac-državnik Václav Havel, onaj koji ima širi interes od svoga vlastitoga, koji ima veće moralne zahtjeve, koji zbog šireg zanimanja i dubljeg gledanja ispod površine fenomena i suodnosa među događajima, osjeća i veću odgovornost za druge, za svijet, a ne brine se samo za sebe. ${ }^{19}$

Intelektualac demaskira verbalizam i demagogiju, zaustavlja duhovno pustošenje od strane neargumentiranog aktivizma, kao i onu najpogubniju izdaju - intelektualno služenje vlastodršcima i tiranima. Pritom nalazi dublje razloge djelovanja i razotkriva zadnja uporišta tehnologije vlasti. Prepoznaje »znakove vremena«, ali ne samo njihovo površno nego i ono dublje, često skriveno značenje. Odgovorno pazi na posljedice svojih riječi i postupaka, predlaže alternativu i ondje gdje vlada indiferentizam, sterilni kritički pesimizam ili samodostatnost, $i$ ondje gdje se misli da alternative nema pa izopačena realnost trijumfira nad slobodom mišljenja, nad slobodnom kritikom i slobodnim hrabrim djelovanjem.

Teolog Živan Bezić smatra da je intelektualac »visoko obrazovan čovjek« (pritom ne mora imati visoke škole), »koji unapređuje intelektualna dobra«. Unapređivanje za ovog teologa znači produciranje ${ }^{20}$ i reproduciranje $\mathrm{u}$ prvom redu duhovnih, intelektualnih dobara (religije, morala, kulture, znanosti, umjetnosti). Prednost imaju produktivni intelektualci, duhovni stvaraoci, ali - prema Beziću - nezamjenjiva je uloga i »reproduktivnih intelektualaca« koji čuvaju, prenose i tako unapređuju kulturna dobra. Uostalom, nijedan produktivni intelektualac ne počinje od početka, nego usvaja dosegnuto i stvara nešto novo.

Vrijednu klasifikaciju intelektualaca nudi Đuro Šušnjić. ${ }^{21}$ Prema ovom sociologu postoje »neutralni tehničari« koji se distanciraju od događaja, istražuju i prosuđuju činjenice s aspekta vrijednosne i moralne neutralnosti. Oni se egzistencijalno ne upliću u stvarnost, zamjenjuju humanizam scijentizmom. Drugi tip intelektualaca su »socijalni filozofi« koji iz perspektive moralnih načela i univerzalnih ideala kritiziraju postojeće stanje, ali niti nude konkretan način njihove aktualizacije, niti se sami društveno angažiraju da prokla- 
mirana načela i ideale praktično ostvare. Treći tip intelektualaca su »kritički intelektualci«. Iako izrijekom ne navodi, prema ovom sociologu religije, ova vrsta intelektualaca slična je biblijskim prorocima koji polaze od nevolja ugroženih, od socijalne nepravde. Oni tu nepravdu javno tumače, duhovno joj se opiru i postaju glasnogovornici potlačenih. Štoviše, oni se bune i kritiziraju samorazumljivo i sviknuto stanje nepravde, spremni da sami podnesu žrtve kako bi se razriješila muka i ostvarila socijalna pravda. Pritom nisu dogmatični, nego su samokritični, nisu gospodari ljudi i ideja, nego su njihovi služitelji.

\section{Realnost kao sudbina}

Odnos prema realnosti ili društvenom i političkom kontekstu temeljni je kriterij za razumijevanje suvremenih intelektualaca. U naslovu smo postavili intelektualca između dvaju oprečnih ponašanja, fanatizma i cinizma, između dvaju suprotstavljenih odnosa prema realnosti. Ovu oprečnost posuđujemo od njemačkoga filozofa Roberta Spaemanna i primjenjujemo na intelektualca, dok sam autor o tome govori u kontekstu šireg moralnoga djelovanja s obzirom na pitanje koliko možemo mijenjati ono što je bez nas takvo kakvo jest, nepromjenjivo - »sudbinu «, kako Spaemann kaže slijedeći Hegela. ${ }^{22}$ Zalaganje za opće dobro i izgradnja socijalnog mira nezaobilazno su povezani s odnosom prema stvarnosti. Pojmovima fanatizma i cinizma koristimo se, dakle, kao interpretacijskim modelima za razumijevanje načina kako se intelektualci odnose prema društvenoj stvarnosti. Uvažavamo pritom da se ova dva modela u praksi rijetko pokazuju krajnje čisti. Postoje u sebi različiti fanatizmi i cinizmi, ali i pomiješani između sebe. Široka je lepeza pristupa stvarnosti - od distanciranosti tipa anđeoskog purizma $^{23}$ do nasilnih zahvata $\mathrm{u}$ formi revolucije ili svetoga terora.

\section{9}

Prema Havelu, intelektualac je »čovjek koji zahvaljujući sferi svojih interesa i svojoj izobrazbi - uočava među pojavama širi suodnos nego što je uobičajeno. To je, dakle, čovjek koji nastoji ući pod površinu stvari, dodirnuti njihov dublji smisao, veze, uzroke i posljedice, promatrati ih kao dijelove većih cjelina. No ne samo to: to je čovjek - bar prema radnoj definiciji koju ovdje navodim - koji upravo stoga što uočava šire ili dublje suodnose pojava, osjeća i širu ili dublju odgovornost za svijet." Vaclav Havel, Sve je moguće. Izabrani govori, Matica hrvatska, Zagreb 2000., str. 159.

20

»Produktivan intelektualac stvara nova dobra i vrijednosti, on plodno obogaćuje sebe i zajednicu u kojoj djeluje. On je stvaralac u punom smislu riječi jer proizvodi nešto novo i vrijedno. U prave intelektualce oduvijek ubrajamo filozofe, teologe, učenjake, profesore, izumitelje, pronalazače i umjetnike svih grana.«Ž. Bezić, »Tko je i što je intelektualac?«, str. 336.

21

Đuro Šušnjić, »Intelektualac«, u: Milan Martić i dr. (ur.), Enciklopedija političke kulture,
Savremena administracija, Beograd 1993., str. 419-427. Također usp. Zagorka Golubović, »Intelektualci u epohi pomerenih vrednosti«, dostupno na: http://www.republika.co.rs/350351/19.html (pristupljeno 25. 11. 2015.).

22

Robert Spaemann, Osnovni moralni pojmovi, Svjetlo riječi, Sarajevo, Zagreb 2008., str. 109.

23

Papa Franjo navodi četiri načela društvenog života za »izgradnju naroda u miru, pravednosti i bratstvu«: 1) vrijeme je važnije od prostora, 2) jedinstvo prevladava nad konfliktom, 3) stvarnost je važnija od ideje $i$ 4) cjelina nadilazi dio. Pod trećim načelom - stvarnost je važnija od ideje - Papa govori o »raznim oblicima prikrivanja stvarnosti« koje treba izbjegavati: »anđeoske oblike purizma, diktaturu relativizma, praznu retoriku, ciljeve koji su više idejni no stvarni, ahistorijske fundamentalizme, etičke sustave lišene dobrote, intelektualne rasprave lišene mudrosti« (EG 231). O interpretaciji ovih Papinih društvenih načela usp. Stella Morra, Dio non si stanca. La misericordia come forma ecclesiale, EDB, Bologna 2015., str. 110-133. 


\subsection{Nasilje fanatika i lukavstvo cinika}

Fanatik-intelektualac je onaj koji si umišlja da rješenje nesređene (podijeljene, konfliktne) realnosti ima u rukavu, da je sam kreator smisla realnosti. Smatra da smisao nije dan (darovan), nego ga on uspostavlja, mora ga uspostaviti, čak i nasiljem. Koliko je samo intelektualaca i u naše vrijeme aktivno u fundamentalističkim pokretima, nasilnim revolucijama i ideologijama koje se vode stvaranjem novoga poretka, od onih na mikrorazinama do globalnoga svijeta, od svakodnevne isključivosti u obiteljima, susjedstvu i institucijama do državnog, entitetskog i svetog (globalnog) terora!

Na drugoj strani je cinik-intelektualac, koji se možda nekada ne samo zanosio vlastitom moću nego i stvarno otkrivao i uspostavljao smisao u složenoj zbilji, no $s$ vremenom se pomirio s nepromjenjivošću realnosti, s pravom jačega (vlasti) i zato u dilemama skreće u oportunizam i pasivnost, apatiju i rezignaciju, etički relativizam i nihilizam. Zauzeo je stranu besmislene zbilje i traži kako da najbezbolnije sačuva sebe, ugled i svoju udobnost. ${ }^{24}$ I kao što ima raznih vrsta fanatika, od onih salonskoverbalnih, agresivnih na riječi čiji učinak prestaje u dodiru sa stvarnošću pa sve do zastrašujućih fanatika koji proizvode sveti teror, siju smrt i uništavaju ljude i svijet, tako ima i raznih tipova cinika.

U cinike možemo ubrojiti »sterilne pesimiste« čija kritika samo ljeporječivo odzvanja, zauzima javnu scenu i time priječi promjenu realnosti. Zatim su tu oni koji su se zatvorili u vlastite »zlatne osame« i nijemost samodovoljnosti opravdavajući svoju neodgovornost moralnošću čistih ruku. Mnogo je danas »dežurnih intelektualaca«, »intelektualaca ideologa $\mathrm{i}$ »populista« koji »rade« samo za novac i za onoga tko ih bolje plati. Postoje i oni rezignirani koji poništavaju svaku društvenu nadu i smisleni angažman, bilo da smatraju kako je zlo realnosti premoćno, bilo da lažno projiciraju u ovostranu budućnost (povijest će pokazati!) ili u eshaton (Bog će već sve prosuditi!) konačni pravorijek njihova ispravna oprezna (ne)djelovanja. Međutim, ušutkavanjem, krivotvorenjem i represijom - primjećuje Vlado Gotovac u susretu s ciničnim stavom velikog Krleže - ne omogućuje se budućnost. »Bjelodanom nije potrebno drugo doba! A posmrtne rehabilitacije spadaju u bezočne smicalice« - nastavlja Gotovac - »jer mrtve ne uskrsavaju a njihove ubojice amnestiraju - kad im ne vraćaju nevinost. U budućnosti se može učiniti samo drugo - ako je uopće bude. ${ }^{25}$

\subsection{Prihvaćanje i stvaralački otpor prema realnosti}

Jedno je sigurno, ni fanatik ni cinik nije zadovoljan postojećim, ne miri se s realnošću. No ni jedan ni drugi nije se sljubio, pomirio s »besmislenom《 realnošću da bi je ispravno mijenjao. Da se promijeni realnost, da se promijeni ono što se označava sudbinom, nužnim i nepromjenjivim, prvi je uvjet da se realnost prihvati. Iz njemačke srednjovjekovne mistike navedeni Spaemann preuzima pojam »opuštenosti«, "pripuštenosti« (Gelassenheit), kao srednji, mudri put i rješenje između fanatizma i cinizma. »Pod opuštenošću« - piše Spaemann - »razumijevamo držanje onoga koji ono što ne može mijenjati prihvaća u svoje htijenje kao smislenu granicu svoga djelovanja, koji prihvaća granicu «. ${ }^{26}$ Sprijateljiti se s realnošću i kada je ona neprijateljska, nastavlja filozof, znači »sprijateljiti se s nama samima«, a »bez prijateljstva sa samim sobom ne može biti dobrog života «. ${ }^{27}$

Nadovezujući se na ovu misao, opušteno prihvaćanje nesnošljive i nepromjenjive zbilje, taj prvi korak za njezinu promjenu, s onu stranu zapaljivog fanatizma i apatičnog cinizma, mogli bismo izraziti biblijsko-teološkom riječ- 
ju predanje. I s ovom riječi valja biti oprezan. Ona je naročito opterećena različitim tumačenjima u propovijedima i kršćanskoj duhovnosti. Duhovnici i pobožnici najčešće je razumijevaju kao slijepu i podaničku poslušnost Božjoj volji utjelovljenoj u poglavarsku volju. Predanje, međutim, treba shvatiti u širem i dubljem smislu. Utemeljenje za to nalazimo u evanđelju, u Isusovom prihvaćanju nerazumijevanja, krive osude, patnje i smrti, jednom riječju u svjesnom i slobodnom prihvaćanju zbilje križa.

Isus ne smatra križ smislom svoga života, nego nametnutom nesrećom, upravo od strane religijskih i narodnih poglavara. Razapinjane na križ je istodobno najsramotnija smrt na koju je rimska vlast osuđivala političke pobunjenike. Takvom križu Isus mijenja smisao. Križ postaje sredstvo ljubavi za obraćenje ljudi i za promjenu njihova odnosa prema Bogu i promjenu uzajamnih odnosa. Zahtjev predanja (smrti na) križu, što je mnogo više od znaka i simbola, više od dvije grede mučilišta, Isus postavlja kao uvjet učenicima da ga nasljeduju:

»Hoće li tko za mnom, neka se odrekne samoga sebe, neka uzme svoj križ i neka ide za mnom« (Mt 16,24)

Tako predanje na smrt na križu nije vlastiti izbor, nego nametnuta i neizbježna situacija.

Predanje znači prihvatiti svijet i zbilju, okolnosti i ljude oko sebe kao vlastite, kao dio samoga sebe, kao svoju sudbinu, kao jedino osobno vrijeme i prostor, kao vlastitu omeđenost drugima, kao ulazak u njihovu situaciju. U konačnici, kako to izriče vjernik po uzoru na umirućeg Isusa na križu, riječ je o »Bož-

24

Prema riječima Vlade Gotovca mogli bismo velikoga Miroslava Krležu u njegovim poznim godinama označiti intelektualcem koji se više nije opirao stvarnosti, nego je rezignirao. U susretu koji je Gotovac odredio kao njihov posljednji, Krleža je tražio da se Gotovac povuče iz javnosti, da ušuti, te da mu on može pomoći samo ako Gotovac ode na odmor koji će mu on plaćati, što ovaj ni zamisliti nije mogao. Krleža je reagirao »uvredljivo« $\mathrm{i}$ »bijesno« na Gotovčevu primjedbu da se $\mathrm{Kr}$ ležina ocjena o njemu i drugim pojedincima u hrvatskom proljeću 1971. u potpunosti slaže s ocjenom službene (totalitarne) vlasti. Krleža je odbio mogućnost javnog angažiranja kao i Gotovčev prijedlog da oko važnih pitanja »)javno istupi«: »Krleža je moj prijedlog odbio, tvrdeći da ga nitko uopće ne bi ni čuo, kad bi i govorio, ili bi ga krivo čuli (...). Sada se može i mora čuti samo službeni glas. Opirati se tome znači stavljati glavu na panj. (...) Ništa se ne može promijeniti. Moram se baviti nečim drugim. Bar za dogledno vrijeme. Konačna ocjena ovih događaja stvar je budućnosti. U tom trenutku« - nastavlja Gotovac - »ja sam ustao sa stolice. On je zastao u pola rečenice. Stajao sam neizrecivo tužan pred starim gorostasom, zapetljanim u bijeg po stranputicama, gdje se na kraju šutnja kombinira s ugledom i pruža azil, čije se udobnosti i mir više ne mogu dramatično iscrpiti u njegovom životu. (...) Poslije svega, kao zaključak, kao konačna mudrost, ostalo mu je uvjerenje, da više ništa ne može promijeniti; da je potpuno svejedno što čini, jer posljedice su uvijek iste. Mogao je birati samo između mirne $\mathrm{i}$ udobne starosti i samoubilačke ludosti, uzaludnog stradanja... - budući da se jedino još njegov privatni život u svakom trenutku mogao promijeniti. Gledao sam ga s jednog od onih mjesta koja je on podigao i znao sam da je ovo naš posljednji razgovor.« V. Gotovac, Moj slučaj, str. 150-152.

25

V. Gotovac, Moj slučaj, str. 152. 26

R. Spaemann, Osnovni moralni pojmovi, str. 115 .

U kontekstu milosrđa naočigled nedužne patnje i teolog Kasper navodi njemačke mistike koji su govorili o »opuštenosti« kao »ostavljanju i napuštanju, koje oslobađa i posve se prepušta Bogu, nasuprot imanju, prianjanju i vezivanju, koje zarobljava«. Riječ je o »mudrosti nade« u Božje obećanje spasenja, nade »koja nije prazna čežnja ni puka jeftina utjeha. Ona nam već ovdje i sada daje svjetlo i snagu. Mi u ovom svijetu ne sjedimo takoreći u čekaonici vječnosti i samo čekamo da nam se otvore vrata u život. Nada je aktivna i aktivirajuća snaga«. Walter Kasper, Milosrđe. Temeljni pojam evanđelja - ključ kršćanskoga života, Kršćanska sadašnjost, Zagreb 2015., str. 168-170.

27

R. Spaemann, Osnovni moralni pojmovi, str. 158. 
jem davanju «, u kojem vjera prerasta u totalni čin pouzdanja u Boga. Unatoč ljudskoj nemoći suprotstavljanja, unatoč i onom najtežem iskustvu Božje odsutnosti, Božje će dobro a ne ljudsko zlo imati posljednju riječ. Jer nisu samo ljudi kreatori i gospodari povijesti nego je to i Bog. ${ }^{28}$

S realnošću koju ne možemo mijenjati mi se »mirimo« (slično kako to Isus čini u Getsemaniju, uz tjeskobu i krvavi znoj). Mirimo se tako da ne izdajemo načela svoga djelovanja te stvaralački odgovorno dalje postupamo. Nenasilno se opiremo besmislenosti zbilje i time, ne pasivno, nego aktivno vjerujemo bez ikakva čvrsta uporišta, aktivno ljubimo i ondje gdje ljubav djeluje besmislena, aktivno se nadamo i ondje gdje sve ukazuje na nužnost rezignacije i očaja. Pomireni sa stvarnošću, prikovani na nju, mi joj se opiremo i kada uopće ne znamo za dobar ishod našeg djelovanja, mijenjamo njezine makar rubne uvjete, a možda stvaramo i neke nove, povoljnije uvjete za druge u naizgled bezuvjetnoj i beznadnoj situaciji.

Realnost, dakle, koliko god djelovala nepromjenljivo zadana, ipak nije »vječno« nepromjenjiva. Prva i najteža promjena realnosti, koja nam se uvijek nameće kroz neki oblik sile i nasilja jačih od nas, jest njezino nenasilno prihvaćanje, opušteno pripuštanje.

»Promjena je moguća samo na temelju onoga što jest i što je kao takvo spoznato, priznato i prihvaćeno. $\ll^{29}$

Opušteno prihvaćanje nesnošljive realnosti, gledanje u oči realnosti bez bijesa i srdžbe, bez mržnje i očaja, s ljubavlju i aktivnom nadom, s konkretnim angažmanom i djelima milosrđa, istodobno je nemirenje s njom, stvaralački otpor njezinoj dominaciji, neposluh i nepokoravanje njezinoj logici. Riječ je, u konačnici, o afirmaciji intelektualne slobode kao afirmaciji dostojanstva čovjeka pojedinca nasuprot fanatizmu kolektivnoga nasilja i nasuprot ciničnim kompromisima. U tome leži i izvor nenasilne građanske hrabrosti.

\section{Dvorski i predstavnički intelektualci}

U našem društvenom kontekstu nezaobilazno je pitanje kako je stalo s intelektualcima u našoj realnosti postsocijalističkog i poratnog društva? U vremenu socijalizma (marksistički) intelektualci su bili povlašteni sloj, jedna vrsta socijalističke i komunističke »buržoazije«, s tek iznimno malom, iako značajnom nekolicinom intelektualnih disidenata, koji nisu pripadali ni »radničkoj klasi« ni »poštenoj inteligenciji«. Nakon što je upravo većina te poštene inteligencije ne samo završila nego stvarala i oblikovala fanatične nacionalističke zvjerinjake i odobravala ratnu industriju smrti, a dio se povukao u izolaciju i cinični oportunizam, današnji intelektualci mahom su odgurnuti na društvenu marginu ili na političko smetlište.

Mnogi intelektualci su zamijenili jednu jedinu partiju drugom, jednoga vođu drugim; predstavljanje ideje državotvornosti različitih naroda bratstva i jedinstva zamijenili su predstavničkom funkcijom jedne etničke zajednice u svojoj čistoj etničkoj državi ili entitetu. Dvorskim intelektualcima i intelektualcima nacionalnih ideologija granice interesa i rada nisu niti bezgraničnost duha niti (znanstvena, umjetnička, moralna, religiozna) kompetencija, nego granice interesa njihovih etničkih i religijskih zajednica.

\subsection{Intelektualci po volji naroda}

Naše vrijeme i društvo preplavljeni su poluintelektualcima koji su, posebno oni najprisutniji, dijelom izrasli iz obavještajnih službi prošloga režima, ako 
ne stvarno, onda mentalitetom. Puno je neslobodnih intelektualaca (autocenzuriranih) koji su se u svom nacionalističkom fanatizmu - nakon prekrajanja granica, nakon promjene geografije i demografije - svesrdno dali na reviziju prošlosti i na reviziju svih identiteta. Naši intelektualci su mahom ogledalo naše predpolitičke i poludivlje »demokracije«. Poput političara oni su predstavnički intelektualci dnevne politike i tzv. »etničke volje«. Preuzeli su interpretativni monopol realnosti i čine to bez odgovornosti za druge i cjelinu. Predstavljaju »narod « u smislu »vulgusa«, etničke mase; glasnogovornici su, reproduktivci i branitelji dominantnog masovnog mišljenja.

»Novi« intelektualci nameću se, dakle, kao jedini legalni i legitimni predstavnici etničke cjeline, kao zastupnici onoga što zavodljivo zvuči, a ne znači ništa osim opasnosti za druge - »bića naroda «, ne, dakle, naroda kao »korporativne osobnosti« s odgovornošću, nego kao podatne mase poslušnika. Ti intelektualci se predstavljaju kao predstavnici i onih ljudi koji im izričito zabranjuju da ih predstavljaju, i one nekolicine intelektualaca i samostalnih ljudi koji se opiru biti puki refleks kolektiva i koji ne dopuštaju da ljudski duh (intelekt) bude zarobljen etničkim i konfesionalnim granicama.

Etničku većinu predstavljaju političari i dvorski, kako bi Gramsci kazao, »organski intelektualci«, »psi čuvari« vlasti i ideologije. ${ }^{30}$ Takvi ideolozi-intelektualci nameću javno mišljenje po kojem samostalnih i slobodnih intelektualaca jedva da može biti, a ako ih ima, oni - smatraju »dežurni« intelektualci - ne predstavljaju nikoga, čak ni sebe, ili »u najboljem slučaju« predstavnici su nekih zavjereničkih i neprijateljskih sila i organizacija, dakle »izdajnici« vlastitoga naroda.

»Predstavnički« intelektualci lišeni su moralne i metafizičke odgovornosti. Zajedno sa svojim političkim vođama, uzurpirali su ne samo etničku volju nego i Božju volju, dakle i politički i duhovni prostor pa od demokracije čine »klerikaturu«. U »klerikaturi« nije pak riječ, kako je to smatrao Benda, samo o klericima intelektualcima (svećenicima i teolozima) nego o kultiviranim duhovima, svim intelektualcima koji su podredili duh političkoj (rasnoj, klasnoj ili nacionalnoj) strasti i ideologiji. ${ }^{31}$

28

Ovaj odnos predanja i otpora prema nepodnošljivoj stvarnosti nalazimo $u$ angažiranom životu, u zatvoru i pogubljenju teologa Dietricha Bonhoeffera u nacističkom logoru, jednog od najvećih kršćana-svjedoka našega vremena, a kojemu je zatvorska pisma njegov prijatelj Bethge posthumno objavio i naslovio Otpor i predanje (Kršćanska sadašnjost, Zagreb ${ }^{2}$ 1993.).

29

Filozof i teolog Stjepan Kušar u šest koraka razvija prihvaćanje i promjenu sebe sama i vlastite stvarnosti na osnovu Božjeg prihvaćanja nas kakvi jesmo te nas Duhom promjene potiče na »samonadilažanje i prekoračivanje sebe u ljubavi i žrtvi«: 1) opažanje i osjećanje u krilu stvarnosti, 2) priznanje (otvoreno $\mathrm{i}$ iskreno priznanje stvarnosti prije etičkog vrednovanja), 3) prihvaćanje stvarnosti, 4) vrednovanje stvarnosti bez iluzije o vlastitoj korektnosti i bez bolesnog samooptuživanja, 5) odabir aktivna, a ne reaktivna stava vodeći se budućnošću i konačno 6) zalaganje i provođenje u djelo. Kušar, uz to, posebno naglašava »koristan razgovor s ljudima koji imaju iskustvo u tim stvarima i koji su u stanju pratiti drugoga u njegovim životnim koracima«. Usp. S. Kušar, Obične stvari i slobodni Bog, str. 90-95.

30

Osvrt na Gramscijevo i Bendino razumijevanje intelektualaca, kao i vlastito shvaćanje koga $\mathrm{i}$ što treba predstavljati intelektualac iznosi Edward Said, »Predstavljanje intelektualca«, dostupno na: http://www.odjek.ba/ ?broj=19\&id=01 (pristupljeno 30. 11. 2015.). Usp. također: Jure Vujić, »Deficit intelektualaca. Gdje su nestali intelektualci?«, dostupno na: http://www.matica.hr/vijenac/487/ Gdje\%20su\%20nestali\%20intelektualci\%3F/ (pristupljeno 1. 11. 2015.).

31

Benda u naslovu knjige (u originalu La trahison des clercs, 1927., $\left.{ }^{2} 1946.\right)$ koristi termin klerici, koji ustvari ne označava tek crkvenjake ni samo teologe, nego intelektualce, sve »duhovnike« u smislu sve ljude duha. Usp. J. Benda, Izdaja intelektualaca, str. 65-66. 
Kao prvi kontrolori politike i vlasti, većina intelektualaca je izgubila borbu s iskušenjima politike i vlasti. Predali su se da ih politika kontrolira i upravlja njima, da politika, kako smatra spomenuti Benda, određuje što je moralno. Prestali su biti budni pred vlašću, pomiješali su Božje i carevo, intelektualno i političko, vjersko i führerovsko, duhovno u najširem smislu i najprizemniju političku pragmu. Postali su zarobljenici svoje predstavničke funkcije, pa se »ispod ruha egzistencijalnog samopotvrđivanja « - kako ističe Havel - »nalazi egzistencija izvlaštena sama sebi, sama sebi otuđena, umrtvljena. Čovjek se okamenjuje u svoju vlastitu bistu.« ${ }^{32}$

\subsection{Intelektualci po Božjoj volji}

»Predstavničke« intelektualce ne mora karakterizirati toliko skromno znanje, koliko intelektualno nepoštenje i lukavstvo uma, moralni kukavičluk, i ako su vjernici, najgori oblik vjerskog licemjerja i dijabolična uzurpacija Božje volje i Božjeg imena. Takvi se shvaćaju kao puki odraz tobožnje volje naroda, kao mesije i božanski poslanici u spašavanju svoga naroda. Krunski primjer, svakako ne jedini, jest glavni protagonist i gospodar rata u ovoj zemlji - pjesnik i psihijatar - Radovan Karadžić. ${ }^{33}$

Karadžić je u bh. skupštini pred početak rata u BiH, u listopadu 1991., jasno kazao što misli o sebi kao intelektualcu. On i njegova stranka koju je vodio, tvrdio je Karadžić, nisu ništa drugo nego samo odraz volje srpskoga naroda. ${ }^{34}$ Nije on subjekt svoje povijesti i svoga djelovanja, nego poslušnik, tumač i izvršitelj »tuđe« volje. Niti on niti njegova stranka kojoj je na čelu ne vode narod, nego oni $i d u$ za narodom. Ustvari, sve je obrnuto: politički voluntarizam, moralnu i intelektualnu mizeriju, ovaj »veliki majstor za falsificiranje stvarnosti « ${ }^{35}$ maskirao je slijepom voljom naroda.

No Karadžić nije ostao samo na tome, nego je bezbožnički ispovjedio i osnovni credo političke religije, osuđenoga etnofiletizma, kazavši da je čak »i Bog u ovom mandatu Srbin«, dakle u njegovom mandatu kao »glavnog« Srbina. To je, prema Bendi, jedna od najvećih izdaja intelektualaca jer »propovijedaju ljudima vjeru u praktično i s pomoću teologije, nudeći im određenu sliku Boga «. ${ }^{36}$ Takvi intelektualci se ne suprotstavljaju »realizmu naroda«, nego postaju njegove najgore sluge, unizuju metafiziku i transcendenciju u blato nacionalnih mitova i nacionalne države.

Ako se ima u vidu ova uzurpacija Božje volje, onda biva jasno da takvi intelektualci smatraju rat po sebi nužnim i moralnim, a sve što čine smatraju ostvarenjem »Božje pravde«. Zato im ratni zločinci postaju Božji miljenici i sveci. Zato »veličaju ratnika na štetu pravednika «, ${ }^{37}$ bezosjećajnost i okrutnost protiv očite Božje zabrane ubijanja i ubojice Kajina. Oni imaju jedan jedini kult - kult boga ratnika, boga ratnog uspjeha. Ravnodušni su prema patnji drugih, preziru slabe, milosrđe smatraju poniženjem. Sve zlo pripisuju drugima, druge sotoniziraju, a svoje zločine pokrivaju »nacionalnim bogom« povijesnoga stradanja i ratnih pobjeda. Sebe i svoj narod izjednačuju s Kristom, ${ }^{38}$ Bogu pripisuju svojstva koja donose praktičnu korist, ponajprije demenciju njihove moralne izopačenosti i poricanje njihovih zločina. »Predstavnički« intelektualci, kao odraz kolektivne volje i volje svoga nacionalnoga boga, prestaju biti osobe sa savješću i osobnom odgovornošću.

\section{Iskušenja i dileme intelektualca u politici}

$\mathrm{U}$ »nacionalnim« demokracijama, koje određuju uski etnički interesi, vlast i politika se koncentriraju u rukama »mesijanskih« etničkih stranaka, još 
preciznije, u rukama etničkih vođa (stožernika). Razumijevanje politike se bitno nije promijenilo u odnosu na totalitarnost komunističkog režima. Promijenjeno je razumijevanje »države«, zamijenjeni su »unutarnji« i »vanjski« neprijatelji. Velik broj nekadašnjih intelektualaca (znanstvenika, književnika, teologa, novinara...), kritičara i disidenata režima, ušli su u »dnevnu« politi$\mathrm{ku}$, angažirali su se u etničkim strankama. Umjesto služenja »centralnoj volji« jedne partije, sada služe isključivo etničkom (nacionalnom) interesu kojeg u većini određuje vođa nacionalne stranke, ili skupina plaćenih intelektualacaideologa, najčešće bez odgovornosti za one druge, za cjelinu društva, države i svijeta. Ideologija nacionalnoga jedinstva obeskrjepljuje kritičnost, slobodu mišljenja i govora. Nacionalna politika pokriva gotovo sve, od šumarstva do zdravstva, od školstva do umjetnosti, i tako se urušava u samoj sebi. Prividom da se svi bave politikom, politički prostor je postao antipolitičan i nekritičan, mediokritetski i divlji, neslobodan i isključiv, te apolitičan jer mnogi odustaju, obeshrabreni da se išta bitno može promijeniti, povlače se u cinizam ili nihilističku zavjetrinu.

\subsection{Personalizacija politike}

Kada politika dotiče ili apsorbira gotovo sve, intelektualcu je teško ostati neovisan, baviti se politikom, a sačuvati moralnu principijelnost. Zato su intelektualci u trajnoj dilemi između idealizma etičkih načela, distanciranosti i ustezanja od konkretnih odluka, s jedne, te pragmatičnosti i »operativnih kompromisa « praktične politike, s druge strane. ${ }^{39}$ Ako se u složenim vremenima kao moralno načelo prihvati zlatno pravilo, makar i u svojoj negativnoj formi - da ne činimo ono što ne želimo da drugi nama čine, dakle ako, kako se

32

V. Havel, Sve je moguće, str. 54.

\section{3}

O srpskim piscima, intelektualcima i njihovoj ulozi u ratu usp. Marko Vešović, »Zvjerinjak«, dostupno na: http://www.sveske.ba/bs/ content/zvjerinjak (pristupljeno 1. 10. 2015.).

34

Dio Karadžićeva govora u Skupštini BiH 15.

10. 1991.: »Gospodo, nisam ja ovdje nastupio kao bog rata kao što me je netko počastio epitetom iz Hrvatske demokratske zajednice nego vam kažem, po stoti put, i u našim razgovorima sam to rekao, ne kreira Srpska demokratska stranka volju srpskoga naroda, ona je tumači. (...) Srpski narod zna što vi hoćete... Ja vas još jedanput molim, ne prijetim nego molim, da ozbiljno shvatite tumačenje političke volje srpskoga naroda koju ovdje zastupa Srpska demokratska stranka i Srpski pokret obnove, a poneki Srbin iz drugih stranaka.« Dostupno na: https://www.youtube. $\mathrm{com} /$ watch? $\mathrm{v}=\mathrm{Xtk} 5 \mathrm{LG} 8 \mathrm{xvfw}$ (pristupljeno 20. 11. 2015.).

35

Marko Vešović, » Žitije svetoga Radovana Karadžića«, dostupno na: https://www.bhdani.ba/ portal/arhiva-67-281/113/t134a.htm (pristupljeno 20. 12. 2015.).
36

Usp. J. Benda, Izdaja intelektualaca, ovdje str. 142; vidi šire: str. 130-143.

37

Za potvrdu ovih Bendinih riječi usp. Radovan Karadžić, »Da li je ovo bio rat?«, u: Radoš M. Mladenović, Jerođakon Jovan (Ćulibrk) (ur.), Jagnje Božije $i$ zvijer iz bezdana. Filosofija rata, Svetigora, Cetinja 1996., str. 27-30.

38

»Zbog toga se duboko klanjam jedinom narodu, Kristolikom mučeniku, srpskom narodu u Bosni, koji 'uredno prima sve udarce' sudbine (Sladoje), i za čije viteštvo treba druga znanost i neki drugi Clausewitz. Za sada, njega izgleda razumije jedino sami Bog.« R. Karadžić, »Da li je ovo bio rat?«, str. 30.

39

Havel opisuje intelektualce koji brane »kemijski čiste principe«, koji se kolebaju i ustežu od konkretne političke odluke filozofskim meditacijama i nerazumljivim refleksijama: »Ondje gdje bi se morao ponašati pragmatično i biti otvoren operativnim kompromisima, prisjeća se svoje principijelnosti i postaje nekomunikativan; ondje gdje bi, naprotiv, morao stajati iza svojih principa i riskirati sukob, prisjeća se ideje tolerancije i počinje se čak pretjerano i gotovo mazohistički uživljavati u položaj svojih protivnika«. V. Havel, Sve je moguće, str. 45. 
to pučki kaže, nastojimo »sačuvati obraz«, intelektualac ipak ne može ostati neutralan, u neaktivnoj nedodirljivosti i nezavisnosti, u »purizmu« idealne pozicije, nego se treba konkretno i odgovorno angažirati. ${ }^{40}$ Taj angažman treba biti motiviran maksimalnom obvezom činjenja dobra za druge i protivnike, ne dakle isključivo za »svoje«, »naše« (moju stranku, moj narod). A nikada političko djelovanje ne smije biti upravljano jedino vlastitom promocijom i karijerom, samoljubivim interesom i vlastitim profitom, inače će politika i vlast biti sami sebi svrhom, što je smrt politike.

Osim zavodljivosti vlasti i privilegija koje s njome idu, slavohleplje, demagogija i populizam su stalne i najčešće perfidno zamaskirane kušnje intelektualcima u politici. Intelektualac izdaje svoj poziv ako je njegovo djelovanje motivirano da bude slavljen, ako je »svodnik masa«, ako od Führera postaje Verführer (zavodnik), ako uživa u ponižavanju drugih, unošenju straha i boli drugima. Intelektualac niječe sebe ako populističkim parolama odslikava trenutnu volju vođe ili želje naroda (ili građana), ako kritički odgovorno ne oblikuje i usmjerava javno mišljenje, volju skupina i pojedinaca prema zajedničkom dobru i onda kada je to praćeno nerazumijevanjima i poteškoćama. Nije intelektualac onaj u kome prevagnjuje nezajažljiva pohlepa za novcem i imanjem ili strah da se nikomu ne zamjeri. Intelektualac ne čeka idealnu situaciju da izdvoji svoje istinito mišljenje i izrekne pravednu riječ pred većinom koja se već krivo odlučila. Njega upravo resi osjećaj za vrijeme, za pravi trenutak i odgovornu samostalnu odluku.

Intelektualac u javnosti (u politici) se ne udvara i ne nastoji se svidjeti, nego pred sebe i druge stavlja mnogo više zahtjeve, teži put i »nepopularne istine« od onih kurentnih i lako prihvatljivih. Ne iscrpljuje svoj govor i djelovanje samo u borbi protiv stvarnih ili konstruiranih protivnika i neprijatelja, nego "pridobiva ljude za dobru stvar, iako im se ona « - kako ističe Havel - »s gledišta trenutnih interesa, može učiniti neugodnom «. ${ }^{41}$ Bez sumnje, daleko je popularnije i lakše hraniti mit o ugroženosti ili održavati se u politici sukoba sa zlim, "povijesnim neprijateljem«, u konfliktu s drugim i tuđincem od kojega nam tobože dolazi prokletstvo i aktualna nesreća, nego shvaćati i voditi politiku stvaranja prijateljstava. ${ }^{42}$

U predstavničkim demokracijama, niti »predstavništvo« niti ikoje tijelo vlasti ne bi smjeli poništiti osobnost predstavnika. Među glavnim oznakama demokracije i jest poštivanje dostojanstva svake osobe i njezinih razlika. Tako i intelektualac u politici nije »totalni« poslušnik, depersonalizirani slijepi predstavnik »sistema« ili mehanički glasnogovornik nečijeg mišljenja, niti svoj glas bezrezervno utapa u unaprijed zadano ili nametnuto jedinstvo. Nije odraz masovnog (kolektivnog niti stranačkog) mišljenja, nego onaj koji se njemu opire i mijenja ga ako se krše ljudska prava i poništava dostojanstvo bilo kojeg pojedinca i ako biva odsutna odgovornost za cjelinu. Mandat poslanika i legitimitet izabranih predstavnika nije iznad moralne obveze koja proizlazi iz humanosti, ljudskih prava, iz osobne savjesti; nije iznad poziva biti autonoman čovjek ili, ako je vjernik, ne može izmaći izvan regulacijskog obzora evanđelja i vjerskih normi.

\subsection{Oduhovljenje politike}

Intelektualac u politici i poslovima od zajedničkog interesa čuva se parcijalnoga svrstavanja i gole borbe za vlast. On oduhovljuje politiku, vraća joj moralnost i čini je univerzalno ljudskim poslom time što političkoj odgovornosti potvrđuje metafizičko podrijetlo. ${ }^{43}$ Ustaje protiv straha i sijača straha. Ne straši ljude ni sobom ni drugima, nego čuva ljude od vlastitoga zla, osobnog 
i kolektivnog, od vlastite neljudskosti; kontrolira nasilje i mržnju. Ne straši se poraza i ostavljenosti, prezira i gubitka. Ne gubi glavu ako nije prihvaćen među svojima i čuva se manije popularnosti. Kombinira nastup u javnosti i sabranu samoću, pokazivanje i povlačenje. Kontrolira svoju agresiju, provjerava svoje stavove $u$ knjigama, $u$ tradiranoj mudrosti i među prijateljima koji mu ne podgrijavaju niti ambiciju niti častohleplje nego mu kritički pomažu i hrabre u ljudskosti.

Intelektualca resi oprez pred svakom ideologijom i sistemom, ali nije ni anarhist ni antiinstitucionalan. Odgovoran je za riječ, za druge i za zajedničko. Djeluje u stalnoj svijesti da je dužan istinu i pravdu drugima kao i da svoje postupke izlaže provjeri drugih, i onih koji se s njime ne slažu. Provjerava se pred savješću, a ako je vjernik, i pred bespoštednim sudom Božje riječi. Svjestan je da je svaka autonomija relativna, da je apsolutna sloboda izraz dijabolične volje za moć, te da i pred njim uvijek stoji najteže iskušenje zle moći, izopačene vlasti, privilegijâ i dominacije nad drugima. Sklanja se od aristokratizacije i akademizacije svoga položaja, kao i onog uvijek prisutnog zavodljivoga intelektualnog mesijanizma. Transcendira se detronizirajući se time što je blizak društveno rubnima i strancima, solidaran s obespravljenima, osjetljiv za socijalnu pravdu, opušten i samoironičan.

U atmosferu uobičajenog političkog patosa koji se često rađa ishitrenim i nedovoljno domišljenim odlukama, intelektualac unosi opuštenu temeljitost, kritičnost i samokritičnost, subverzivni i relativizirajući ton. U situacijama zagriženoga strančarenja i »većinskih« procjena i osuda, uvažava pogled »druge« strane, posebno stajališta manjina. Njeguje empatičnost i solidarnost

40

»[U] konkretnim historijskim uvjetima« - kazao je francuski društveno angažirani vjernik Emmanuel Mounier - »u koje smo stalno uronjeni, htjeli to ili ne, imamo određeni broj dužnosti, koje su dužnosti odluke i angažmana, te postavljati probleme izvan tih povijesnih situacija, zbog nekakve idealne čistoće znači u biti izmicati svojoj ljudskoj sudbini. Svako je angažiranje nečisto. Povijesne su situacije uvijek ispremiješane. Nikada i nigdje nećemo naći idealni položaj koji želimo da bismo mogli djelovati kako bismo voljeli.« Emmanuel Mounier, Angažirana vjera, $\mathrm{Kr}$ šćanska sadašnjost, Zagreb 1972., str. 85.

41

V. Havel, Sve je moguće, str. 161.

42

Raspravu o prijatelju i neprijatelju kao temeljnom kriteriju za političko djelovanje pokrenuo je Carl Schmitt, vrsni pravnik, ali i ideolog i teolog nacionalsocijalizma. Schmitt izjednačuje »državu«s »političkim《. Kao što je za moral posljednji kriterij razlika dobra i zla, za estetiku lijepo i ružno, za ekonomiju korisno i štetno (rentabilno i nerentabilno), »ono specifično političko razlikovanje, na kojega se daju svesti politička djelovanja i motivi, jest razlikovanje prijatelja i neprijatelja«. Prijatelj-neprijatelj kriterij posve je autonoman od drugih razlikovanja, smatra Schmitt, pa politički neprijatelj ne mora biti moralno zao ili osobni neprijatelj (odvajanje politike od morala, od evanđelja). Politički neprijatelj, zaključuje Schmitt, jest »drugi, stranac, dostatno je za njegovu bit da je u posebno intenzivnom smislu egzistencijalno nešto drugo i Strano《. Usp. Carl Schmitt, »Der Begriff des Politischen (1932)«, dostupno na: https://www.wzb.eu/sites/default/files/u32/ carl_schmitt_der_begriff_des_politischen 1.pdf (pristupljeno 15. 11. 2015).

Soběhart smatra da Schmitt, u konačnici, nigdje ne definira tko bi ustvari bio neprijatelj, a pogotovo ne prijatelj, nego se radi o »pojmovnoj magiji dva »totalna neprijatelja« totalnoj njemačkoj državi (rat protiv židova i liberalizma). Usp. Radek Soběhart, »Die Begriffe 'Feind' und 'Freund' im Werk von Carl Schmitt«, dostupno na: http://usd.ff.cuni.cz/?q=system/files/ sobehart\%20begriffe.pdf (pristupljeno 15. 11. 2015.).

43

Havel govori o politici s duhovnom i moralnom dimenzijom što isključuje politiku kojoj je jedino stalo do natjecanja u vlasti ili da promiče samo određenu ideologiju i političku koncepciju, nego odgovornost za svijet. Odgovornu politiku resi »odvažnost za zajedničko i solidarno opiranje zlu, volja za dogovor i suradnju, spremnost nadrediti opći i zajednički interes eventualnom osobnom ili grupnom interesu, osjećaj suodgovornosti za svijet i spremnost osobno garantirati za svoje postupke.« V. Havel, Sve je moguće, str. 57. 
u tamnoj borbi protiv »neprijatelja«. Sažeto: odgovornost za cjelinu društva, za vlastitu državu i svijet jedna je od temeljnih zadaća suvremenih političara, $\mathrm{i}$ intelektualaca u politici, gdje je obrana dostojanstva svakoga pojedinca polazište, kriterij i granica svih zauzimanja za ono što se od antike naziva opće ili zajedničko dobro, a koje se, upravo bez poštivanja dostojanstva pojedine osobe, izokreće u svoju pogubnu suprotnost.

\section{Vrijeme teologa}

Među intelektualce se ubrajaju i teolozi bez obzira što to militantni ateisti ili jednostrani sekularisti ne bi željeli niti čuti i bez obzira na činjenicu što se i toliki teolozi cinično izmiču od svoje odgovornosti ili nisu dostojni vlastitoga imena. Ako naše vrijeme i netom započeto 21. stoljeće, između ostalog, označavamo stoljećem buđenja religija, onda teologija i teolozi imaju neporecivu ulogu u njegovu razumijevanju i u rješavanju zajedničkih problema.

Živimo u paradoksalnoj duhovnosti, koju s teologom Metzom možemo najkraće opisati tvrdnjom: religija, da-Bog, ne! Postmoderna je naklonjena religiji, a ustvari je duboko obilježena krizom vjere u Boga, krizom temeljnoga teološkog govora - samim pitanjem Boga ${ }^{44}$ Suvremeni su teolozi, stoga, pred neotklonjivim zadatkom svoga osnovnoga poziva da tako govore, da tako teologiziraju, kako bi Bog došao do riječi, odnosno kako bi i teološki govor i teološka šutnja bili dostojni Boga i čovjeka radi kojega Bog i postoji i radi kojega se objavljuje. U postmoderni, međutim, nije toliko temeljno pitanje Božjega postojanja. Nije vrijeme klasičnih ateizama. Pitanje je karaktera kako Božje djelotvorne ili beskorisne prisutnosti tako i odsutnosti, odnosno, opet Metzovim riječima kazano, o nabujalim duhovnostima i religijama bez Boga.

S pravom se odmah može prigovoriti pa kako to Bog treba doći do riječi, ako je već i previše prisutan, sveprisutan, i to ne samo u »srcima« i privatnostima mnogih ljudi, u raznovrsnim spiritualnostima brojnih suvremenih religijskih pokreta i religijskih uvjerenja. ${ }^{45}$ Štoviše, zar religija i Bog, sa svom svojom ornamentikom, obredima i simbolima, nisu nahrupili u naše škole, po visovima brdâ i gradskim četvrtima, u parlamente, u medije, u stare i nove rasprave o vjerskim pravima i slobodama kako većine tako i manjine, kako religijskih tradicionalista i duhovnih starosjedilaca tako i imigranata, stvarnih ili duhovnih?

Zar Božje ime nije prenâpadno nazočno u zastrašujućem, vjerski motiviranom globalnom nasilju, u svetom teroru, ${ }^{46}$ od onoga teokratsko državnog (entitetskog), preko terora modernih medija (posebno internetskih mreža) prebukiranim religijskim govorom i slikama religijske mržnje, ${ }^{47}$ sve do fizičkoga terora religioznih samoubojica koji po čitavom svijetu siju smrt nedužnih, sve dakle u ime Boga? ${ }^{48}$ Zar onda religije i njihovi bogovi nisu prebučni i prenasilni, zar religije nisu zauzele mjesto politike i revolucije i od Zemlje stvaraju »pakao« pod izlikom Božjeg mira i Božje pravde?

\subsection{Teolozi nacionalnoga}

Ne možemo ne registrirati da su osim političara, mnogi intelektualci, među njima također svećenici/teolozi i religijske institucije, s navalom religije u našu nezrelu demokraciju, a pogotovo u prošlim ratovima, svoje govore i djela započinjali prizivom Božjega imena i začinjali Božjim blagoslovom. Obrnuto proporcionalno onome koliko su prije religija $\mathrm{i} » \mathrm{Bog}$ « bili potisnuti izvan javnosti, u privatnost i sakristiju, sada su postali društveno sveodređujući. Dogodilo se zacijelo unižavanje Božjega imena, radikalno posvjetovnjenje 
svetoga, bestidno ophođenje s božanskom tajnom. Time se - jer Bog nema dostojanstva bez poštivanja čovjekova dostojanstva - dogodilo i krajnje poniženje čovjeka i čitavih zajednica kroz religijsko blagoslivljanje i metafizičku legitimaciju »etničkoga čišćenja«, rušenje i nasilno preseljavanje, ubijanje, ratne zločine i genocid, i to sve ako ne uz izravnu a ono uz prešutno uzurpiranu »Božju volju«. Što je Bog bio javno prisutniji do banaliziranja, to je više obeščašćivan i zatiran u čovjeku.

Nisu, dakle, u naše vrijeme prvotno u krizu zapali religija i njezina javna očitovanja, koliko osobna vjera u Boga i ljudski govor o Bogu - teo-logija, za čiju su »čistoću« odgovorni ponajprije teolozi. Kod nas se ni u komunizmu, a ni poslije komunizma nije razvijala teologija primjerena svetosti Boga i njegova imena u vlastitom pluralnom kontekstu, nikakva, dakle, kontekstualna teologija, osim one tradicionalne, dogmatske i katekizamske te one, u državi privilegiranoga ateizma, nasilno potisnute najsekularnije teologije - teologije nacionalnoga koja je naciju nadredila Bogu, ${ }^{49}$ koja je u ratu i poslije rata buknula kao »sveta vatra« i zapalila društveni prostor. Sažeto kazano, riječ je o teološkoj apologetici nacionalnoga, reduciranoj na banalnu i često prešutno odobravajuću sakralizaciju nacije, etničke politike i kulta nacionalnih vođa, na institucionalizaciju sakralne mržnje prema drugome, na sakralizaciju etničkoga teritorija, nacionalno-religijskih spomenika, blagdana i nacionalnih mučenika (svetaca). Riječ je i o površnoj folklorizaciji svetoga, sakralnom revizionizmu povijesti i teološkom arhaiziranju nikada postojećeg prošlog zlatnog doba religije i religijske tolerancije.

44

O zaboravu Boga u građanskoj religiji dok ga se istodobno »religiozno slavi« usp. Johann Baptist Metz, Politička teologija, Kršćanska sadašnjost, Zagreb 2004., str. 129-133. O krizi i zaboravu Boga kao »signaturi« našega vremena, o nužnosti »svjedočenja o Bogu $\mathrm{u}$ vremenu bezboštva naklonjenog religiji, $\mathrm{u}$ dobu religije bez Boga usp. knjige: Memoria Passionis. Provokativni spomen u pluralističkom društvu, Kršćanska sadašnjost, Zagreb 2009., str. 93-96; te Pasija za Boga i zbog Boga. Redovnička egzistencija danas, Svjetlo riječi, Sarajevo, Zagreb 2009. str. 21.

45

Ovdje po strani ostavljamo čitavu paletu »duhovnjaštva«, onoga što Eagleton naziva suvremenim »religioznim iluzijama«, »religijama New Agea« koje »nude utočište od svijeta, a ne misiju da ga preobraze«, koje su poput romantizma »reakcija na svijet bez srca«, ali ostaju ograničene »na sferu osjećaja $\mathrm{i}$ vrijednosti«, na privatnost $\mathrm{i}$ intimu pojedinaca. Te vrste duhovnosti i religioznosti su svojstvene današnjem kapitalizmu koji je »inherentno ateistički«. Usp. Terry Eagleton, Razum, vjera i revolucija. Refleksije o raspravi o Bogu, Naklada Jesenski i Turk, Zagreb 2010., str. 46-49.

46

Usp. Terry Eagleton, Sveti teror, Naklada Jesenski i Turk, Zagreb 2006.
47

O medijima koji ispunjavaju sve aspekte društvene uloge religije (interpreti svijeta $\mathrm{i}$ arbitri istine) te o modernom terorizmu koji se domogao medija, te moderne religije i sakralnog prostora svijeta, o terorizmu kojemu su mediji najmoćnije oružje i glavno sredstvo utjecaja, posebno sijanja straha, usp. Tomáš Halík, Strpljenje s Bogom. Pripovijest o Zakeju danas, Svjetlo riječi, Sarajevo 2014., str. 168-184.

48

O problemu nasilja u svetim knjiga, u tradiciji i danas u židovstvu, kršćanstvu i islamu, usp. Jan-Heiner Tück (ur.), Sterben für Gott - Töten für Gott. Religion, Martyrium und Gewalt, Herder, Freiburg, Basel, Wien 2015.

49

Oslanjajući se na Benedicta Andersona, Eagleton piše: »Nacionalizam je zaostali trag transcendencije u sekularnom svijetu. Poput Boga, nacija je besmrtna, nedjeljiva, nevidljiva a ipak sveobuhvatna, bez iskona i konca, dostojna naše najusrdnije ljubavi te tvori sam temelj našeg bića. Poput Boga, njeno postajanje je stvar kolektivne vjere. Ne bi bilo nacije kad mi ne bismo vjerovali da je ima. Ona ne postoji u smislu u kojem postoji Veliki koraljni greben. Ako nacija opstaje zbog vjere, ona jednako tako uključuje političku nadu, umnogome i u svoje buduće oslobođenje; a ujedno predstavlja domenu milosrđa i bratske privrženosti.«T. Eagleton, Sveti teror, str. 92-93. 
Navedeno stanje uzrokovalo je da u našim institucijama i javnim prostorom dominiraju antiteološki (antiintelektualni) duh, nekritični, iracionalni i preuzetni religijski govori i prakse. U takvom kontekstu teolozi iskušava beskorisnost i društveni prezir svojega poziva do mjere da se srame i nazvati teolozima. Naime, slično kao politikom, tako su se i teologijom, vjerom i Bogom počeli baviti »svi«. Promjenom režima u crkvene i religijske zajednice nahrupili su fanatični novoobraćenici te religiozno i teološki nekompetentni apsolutisti.

Umjesto da Bog dođe do riječi, da se vjera pokaže u svom društveno-kritičkom i mirotvorno-utješnom potencijalu, teolozi su dopustili da Bog iščezne u površnoj religijskoj samorazumljivosti kako navodno svi vjeruju te kako je za vjeru dovoljno da Božje ime stalno bude na ljudskom jeziku, u uličnim pozdravima, posvuda na ljudskom dohvatu. U religijskoj buci Bog je zapravo iščeznuo iz budne svijesti ljudi. Posljedica svega je »reakcionarno politiziranje vjere ${ }^{50} \mathrm{i} »$ religijski nacionalizam $\aleph^{51}$ koji se - prema sociologu Dini Abazoviću - »poziva na pravo da upravlja politikom, jer je pomogao u tvorenju te i takve (etno-nacionalne) politike«. ${ }^{52}$

Kako su nam god nasušno potrebni intelektualci u politici, u javnom prostoru, ništa manje našim crkvama, religijskim zajednicama i društvu u cjelini, uza sva zastranjenja, potrebni su teolozi da iznova ukažu na dostojanstvo, ali i "granice« govora o Bogu i na vjerodostojniju religijsku praksu, te da iznova obrazlažu nadu koja ih pokreće. Ne radi se o nekim novim teologijama, teološkim novotarijama, niti nekom teološkom uvozu iz inozemstva, nikakvim tobože preporoditeljskim ili inovacijskim, konzumerističkim i soft duhovnostima za naš religijski »zaostali« svijet. Ne radi se ni o nužnosti da teolozi zamijene političare, da se gube u složenim problemima uređenja društva, kao ni u sitnicama obredoslovlja, nego o bavljenju glavnim pitanjima vjere. $\mathrm{Za}$ naš duhovni kontekst ta bismo pitanja mogli ovako formulirati: Kako se, u svoj složenosti situacije, teološki suočiti s temeljnim pitanjem smisla života, u čemu je nezaobilazno pitanje Boga, bogova i idola? ${ }^{53}$ Kako se to pitanje $i$ odgovor na njega trebaju artikulirati da izražava respekt prema drugima, i vjernicima i nevjernicima, te da kao relevantni budu saslušani i respektirani u religijski pluralnom društvu?

\subsection{Teolozi prosvjetiteljstva iz vjere}

Radi se o teologiji odgovornog ophođenja s Božjim imenom jer je to ime, a onda i sama teologija, uvijek društveno relevantno i s mogućim različitim posljedicama: od ponude utjehe i spasenja, stvaralačkoga nemira do ratova i ljudskih strašnih nesreća. Riječ je o društveno-kritičkoj moći vjere i »osloboditeljskoj snazi sadržaja riječi $B o g$ « ${ }^{54}$ Naše vrijeme, naše religije i vjerske zajednice vape za »teološkim prosvjetiteljstvom « koje se u nas, a i u nekim drugim područjima svijeta, uslijed dominantnih nacional-teologija i politiziranih religija, i dalje marginalizira ili posve odbacuje.

Kada kažemo teološko prosvjetiteljstvo mislimo na teologiju bližnjega/drugoga, na teološku refleksiju o vjeri u Boga i njezinom središtu, teologiji Božjeg imena koja je neodvojiva od teologije čovjekove slobode, slobode vjerovanja i nevjerovanja jer se ni Božje ime ni čovjekova sloboda ne dopuštaju zaposjesti. Riječ je o teologiji Božjega imena, imena koje se ne nudi samo onima koji vjeruju kao ja i mi, nego i slobodi onih koji se, pogotovo uslijed zloupotrebe pervertiranih teologija toga imena, distanciraju ili zahtijevaju šutnju o Bogu pa čak i njegovo »nasilno « uklanjanje iz javnoga prostora. Riječ je o teologiji koja izrasta iz osnovnog objaviteljskoga podatka vjere: unatoč svim ljudskim imenovanjima, unatoč svim govorima o Bogu, unatoč svim teo-logijama, Bog 
ostaje neizreciv ljudskom jeziku, ali nikada apsolutno nepriopćiv. To je srž teološkoga prosvjetiteljstva i razlog postojanja teologa u vjerničkoj zajednici i društvu. Bog se nudi čovjekovoj slobodi. Neotuđivo čovjekovo dostojanstvo i sloboda su »konstrukcijski princip $\aleph^{55}$ svake teologije i vjerničke prakse.

Teološko prosvjetiteljstvo odnosilo bi se, dakle, na već postojeću, iako često samo deklarativnu, neuvjerljivu i zanijekanu ekumensku teologiju, teologiju međureligijskoga dijaloga kao i dijalošku teologiju s distanciranima, agnosticima i ateistima koji apriori ne isključuju drugost drugoga ni transcendentnu i duhovnu dimenziju čovjeka. ${ }^{56}$ Ta vrsta teologije pokretana je »epistemološkim altruizmom«, dijaloškom otvorenošću za mišljenje i stavove onih drugih, motivirana je empatijom i solidarnom praksom za najslabije, onako kako se vjeruje da sam Bog čini u svom naumu spasenja ljudi.

Ako se sada vratimo našoj glavnoj tezi o nužnosti da se intelektualci u opravdanom nezadovoljstvu sa stvarnošću u toj stvarnosti angažiraju bez fanatizma i cinizma, opušteno je prihvaćajući, opirući joj se uz stvaralačko, odvažno i strpljivo mijenjanje, možda samo i rubnih uvjeta, onda su današnji teolozi pred zadatkom odgovora na krizu vjere u Boga, a ne primarno na krizu religije i na moralno urušavanje religijskih institucija. Niti ovdje nije odgovor $u$ fanatičnom, nasilnom izvikivanju Božjeg imena uvijek i posvuda. Odgovor nije ni u ciničnom povlačenju u šutnju, u obeshrabrenu uzaludnost teološkoga govora i beskorisnost nominacije Boga u složenom i negdje ideologijom

50

Usp. J. B. Metz, Politička teologija, str. 15.

51

»Religijski nacionalizam dakle upravo inzistira na simbiozi političkog i religijskog, na nacionaliziranju konfesije koja prethodi religiziranju politike, što je reminiscencija na predpolitičko doba, kada se religijski establishment pozivao na pravo da upravlja $\mathrm{dr}$ žavom jer je religija bila bitan (ili najbitniji) element za njeno uspostavljanje.« Dino Abazović, "Za naciju i Boga«. Sociološko određenje religijskog nacionalizma, Magistrat, Centar za interdisciplinarne postdiplomske studije, Sarajevo 2006., str. 106.

52

D. Abazović, »Za naciju i Boga«, str. 107.

53

Navodeći mišljene teologa Paula Tillicha, Bubalo smatra da je zadaća teologa »ne samo s krajnjom ozbiljnosti postavljati pitanje o onome bezuvjetnom koje nas se tiče, nego u svjetlu te instancije davati odgovore na probleme života i pitanja vremena. (...) teolog 'mora otkrivati lažne bogove u duši pojedinca i u društvu', 'istražiti njihova najtajnija skrovišta', ući u teološku polemiku protiv bogova i demonskih likova, protiv iskrivljenja Boga u mišljenju i djelovanju. Na toj razini nije dopušten nikakav kompromis, nikakvo prilagođavanje i nikakvo teološko izmicanje. Jer, stijena na kojoj teologija stoji jest prva zapovijed. Tu nije moguća nikakva sinteza između Boga i idola.« I. Bubalo, »Teološko obrazovanje u vrijeme krize intelektualaca«, str. 70.
54

» Teologija, koja u tom smislu želi biti i ostati kritička odgovornost kršćanske vjere i njezine predaje, ne može stoga a da se u svojoj srži ne osvrće na društvene i praktične odnose. Teološka teorija ne dopušta da se apstrahira od problema javnosti, prava i slobode. U svojem polazištu ona uvijek mora misliti na posljedice koje nastaju kad se u određenoj situaciji govori ili šuti o Bogu. Ona mora misliti i na posljedice koje taj govor izaziva u određenoj situaciji.« J. B. Metz, Politička teologija, str. 93-94.

55

Ovu misao posuđujemo od teologa Kaspera iz njegova govora o socijalnom nauku Crkve. Nije riječ, kako navodi Kasper, o »individualističkoj slobodi samovolje« koja se u politici lako može preokrenuti »u otvoreni i podmukli totalitarizam«, nego o »slobodi koja će uvijek poštivati i slobodu drugoga, biti solidarna $\mathrm{s}$ njom i zauzimati se za nju«, koja se »ostvaruje u pravednosti« jer »svakome daje njegovo«. Usp. W. Kasper, Milosrđe, str. 251.

56

Ne sve, ali mnoge forme suvremenoga ateizma karakterizira, s jedne strane, spiritualnost bez Boga te, s druge strane, misao o odsutnosti Boga koja je nerijetko praćena zabrinutošću, tjeskobom i tugom. Riječ je o jednom drugom ateizmu. Usp. Gregor Maria Hof, Ein anderer Atheismus. Spritualität ohne Gott?, Topos, Kevelaer 2015., str. 17. 
sekularizma obilježenom društvenom kontekstu jer je, misle teološki cinici, kriza nesavladiva.

Kako god stvarnost izgledala neprohodljiva, kako god kriza djelovala nesavladiva, u njoj je i rješenje. Kriza je, teološki gledano, uvijek i kairos, povoljna prilika moguće preobrazbe postojećeg stanja na bolje. Kriza je - kazano novozavjetnim rječnikom - punina vremena. U tom smislu današnji su teolozi $\mathrm{u}$ iznimnoj prilici, u jedinstvenom kairosu, prosvjetiteljski djelovati u ime Boga koji je uvijek Bog svih ljudi i Bog koji ostaje neimenovani, nezaposjednuti, koji se nikada bez ostatka ne uklapa u naš jezik, koji nikada dokraja »ne paše ${ }^{57}$ našim vjerničkim i teološkim konstruktima. Proročko-prosvjetiteljsko djelovanje teologa nužno je za Crkvu, religijske zajednice i ništa manje za skladan život u religijski i svjetonazorski pluralnom društvu.

Teološkim prosvjetiteljstvom u ime Boga, koji nije nekomunikabilan, ali je uvijek neimenovana Tajna, ne zagovara se nikakav teološki integralizam niti vjerski, ovdje konkretno kršćanski totalitarizam tipa teokratske države, nego se u postojećoj krizi poštuje autonomija vremenitih stvari, a onda i autonomija politike i svjetonazorska sloboda ljudi. Takvo prosvjetiteljstvo iz vjere aktivno je sudjelovanje u društvenim događajima, bez dogmatskih dedukcija, ali i bez bijega u društvenu neutralnost ili teološki nerelevantnu duhovnost. Takvo prosvjetiteljstvo dovodi u krizu ideološke (rasne, etničke, klasne) mesijanizme, razne zavodljive idolatrije ${ }^{58}$ i perverzne kultove ličnosti, proizlazili oni iz ideologije sekularizma ili iz ideologije političke religije. Teološkim prosvjetiteljstvom humanizira se društvo, vraća se dostojanstvo čovjeku pojedincu i smisao angažmana za zajedničko dobro, ne dopušta se uspostavljanje kulta zemaljskoga boga niti prizemno zaposjedanje božanskoga Boga.

\section{Zaključak}

U ovom članku istaknuta je kompleksnost značenja pojma intelektualac i prijepornost razumijevanja njegove uloge $\mathrm{u}$ javnom životu posljednjih stotinjak godina, od Dreyfusove afere do u naše vrijeme. Istodobno je podcrtana nužnost društvenoga angažmana intelektualaca, njihov odnos prema realnosti koju - bez fanatizma i cinizma - treba opušteno i stvaralački mijenjati. Konstatiran je neotklonjiv zahtjev da se u društveni život vrati kritičnost, kompetentnost i moralnost, s posebnim naglaskom na odnos intelektualaca prema politici i vlasti te na angažman intelektualaca u politici. Pritom je postavljeno načelo odgovornosti za cjelinu, za svijet, za zajedničko dobro kojemu su polazište, kriterij i granica djelovanja poštivanje i obrana dostojanstva svake osobe.

Poseban odjeljak u članku čini osvrt na nedostojnu, a neporecivu ulogu teologa u našem postsocijalističkom, ratnom i poratnom društvu. U postmodernom vremenu »naklonjenom religiji bez Boga«, u vremenu nabujalih duhovnosti i političke religije do njezina najizopačenijeg sekularnog izraza u nacionaliziranoj i retradicionaliziranoj religiji kao i u onom najpogubnijem njezinom očitovanju - u svetom teroru, teolozi imaju iznimnu priliku i neotklonjivu obvezu teološkoga prosvjetiteljstva. To se prosvjetiteljstvo odnosi na temeljni "predmet« teologije - na ime Božje, na vraćanje dostojanstva tajne Boga te na relevantnost Božjega imena u religijski i svjetonazorski pluralnom društvu i svijetu uz respekt čovjekova dostojanstva i slobode. 


\title{
Ivan Šarčević
}

\section{Intellectual Between Fanaticism and Cynism}

\begin{abstract}
The aim of this paper is to provide an answer to the question of who are intellectuals and how much are they needed to society and the Church? Countless intellectuals, among them also theologians, played a role in creating and sustaining destructive regimes of contemporary ideologies, fanatical religious movements and cynical politics. In former socialist countries, active humanists, the main carriers of freedom, dissidents and sufferers, were often intellectuals. In postsocialist societies and countries, especially in Southeastern Europe, struck by war and nationalism, and overwhelmed with triviality of consumer's society, intellectuals/theologians are, next to politicians, the strongest barriers against humanization of society: they exclude morals from politics, they reject self-criticsm, civil bravery and prophetic dimension of faith.
\end{abstract}

\section{Keywords}

intellectual, theologian, fanaticism, cynism, responsibility, the name of God, social engagement, (self)criticism, enlightenment

O Božjem imenu i kušnji zlih bogova, o "paklenom trojstvu« (korisni bog, jaki bog $i$ zli bog) na temelju Isusovih kušnji, a s aktuali- zacijom za naše vrijeme usp. Stjepan Kušar, »Kršćanski govor o Bogu - izazov našem vremenu. Kerigmatsko i parenetsko razmišljanje«, Bogoslovska smotra 68 (2-3/1997), str. 191. 